\title{
Association of Nematodes with Fruit Crops in Bhubaneswar, India
}

\author{
Pranaya Pradhan*, Mukesh Kumar Patra and Niranjan Kumar Sahoo \\ Department of Nematology, OUAT, Bhubaneswar, Odisha, India \\ *Corresponding author
}

\section{A B S T R A C T}

K e y w o r d s
Community
analysis,
Prominence value,
Fruit crops,
Nematode, Odisha
Article Info
$\begin{aligned} & \text { Accepted: } \\ & 15 \text { April } 2020 \\ & \text { Available Online: } \\ & 10 \text { May } 2020\end{aligned}$

A survey was carried out to study the distribution of plant parasitic nematodes associated with fruit crops of Bhubaneswar- The capital of state Odisha, India. Around 240 soil samples were collected from the rhizosphere of fruit crops; cashew nut, guava, papaya and lime across the different places of Bhubaneswar. Nematodes were isolated by Cobb's sieving and decanting method followed by modified Baermann's funnel technique. Communities of plant parasitic nematodes were analysed. The analysis of nematode community revealed the association of 13 nematode species with these fruit crops. Rotylenchulus reniformis was found above pathogenic level which cause disease incidence in fruit crops in different places of Bhubaneswar. Other nematode species reflected low densities which were below pathogenic level. In consideration to prominence value of plant parasitic nematodes Rotylenchulus reniformis exhibited highest Prominence value(207.85), followed by Helicotylenchus dihystera (36.08), Tylenchorhynchus mashhoodi (21.52), Hoplolaimus indicus (19.77), Meloidogyne spp(11.66) and Aphelenchus avenae found the lowest prominence value as (3.74).So far as the free living nematodes are concerned Dorylaimids were having the highest frequency of occurrence (232) with absolute frequency (96.67\%) followed by Rhabditid (93.33\%)and Mononchid (80\%). Dorylaimid was also having highest density (52.68) followed by Rhabditid (36.64) and Mononchid (23.79).

\section{Introduction}

India ranks as the second largest producer of fruits after China. It has emerged as the largest producer of fruits like mango banana, sapota, papaya, and acid lime as well as plantation crops like coconut, arecanut, and cashewnut. Apart from that, new crops like kiwi fruit, olive and oil palm have been successfully introduced for commercial cultivation in the country. Despite the augmentation of fruit and vegetable production in the country, major constraints in production of fresh fruits and vegetables are non-availability of quality seeds or planting materials, inadequate irrigation, lack of integrated nutrient management, huge postharvest losses and risk of pests and diseases. Among various pests and diseases, the role of plant parasitic nematodes in limiting the production and yield of fruits cannot be ruled out. They caused projected yield loss 
of twelve.3\% (\$157 billion dollars) worldwide. Out of that $\$ 40.3$ million is reportable from Republic of India.

The alarming problem of citrus nematode (Tylenchulus semipenetrance) in citrus at Aligarh, Root knot nematode (Meloidogyne incognita) and citrus nematode in pomegranate in Maharastra, devastation of banana crop due to wide spread attack of Radopholus similis in Tamilnadu, Karnataka and Andhrapradesh gear up for a preliminary investigation of nematode survey with various fruit crops such as cashewnut, guava, lime, papaya from the localities of Bhubaneswar. Since study of nematodes in fruit plants is few and far between (Ray and Das, 1989), so it was planned to study the association of nematodes in fruit crops of Bhubaneswar- the capital of state Odisha.

\section{Materials and Methods}

A survey was conducted from different localities of Bhubaneswar, Odisha during the year 2015-2017 to determine the presence of various plant parasitic nematodes associated with certain fruit crops. Requisite soil samples were collected and processed within a week after collection. Subtotal of 240 soil samples were collected from certain plants belongs to fruit crops; such as cashewnut, guava, lime, papaya in different localities placed under the circulance of Bhubaneswar (The city of Temples) Odisha, India.

Cobb's sieving and decanting method was done for the extraction of the nematodes followed by Baermann's funnel technique (Southey, 1986) and nematodes suspension was obtained. Killing of nematodes and fixing in formalin glycerol fixative was used followed by counting the fixed nematode population /200 cc soil sample was done in a multi chambered counting disc under a stereoscopic binocular microscope and identification of nematodes done by observing the nematode morphology and characteristics. Infected roots were stained in cotton blue lacto phenol solution and observed for the presence of nematodes. Communities of plant parasitic nematodes were analysed for computing absolute frequency, relative frequency, absolute density, relative density and prominence value as per the following formulae given by (Norton, 1978).

\section{Absolute frequency}

$=[$ Number of samples containing a species $/$ Number of samples collected] $\times 100$

\section{Relative frequency}

$=[$ Frequency of species / Sum of frequency of all species] $\times 100$

3. Absolute density $=$ Number of individuals per unit of soil.

\section{Relative density}

$=[$ No. of individuals of a species in a sample / Total of all individual of a sample] $\times 100$

5. Prominence value $(\mathrm{PV})=$ Absolute Density $\sqrt{ }$ Absolute Frequency

\section{Results and Discussion}

During the year 2015-2017, 240 soil samples were scooped from the rhizosphere of various fruit plants like cashew nut, guava, lime, papaya in different localities of Bhubaneswar, Odisha. After processing the soil samples through Cobb's sieving and decanting technique (Cobb, 1918) followed by Modified Baermann's technique clear nematode suspension was obtained. The nematode suspension includes various plant parasitic nematodes. Community structure of plant parasitic and free living nematodes associated with these fruit plants in different places from Bhubaneswar has been presented in the Table-1 and Table-2. 
The analysis of nematode community revealed the association of 13 nematode species with these fruit crops. Among the different plant parasitic nematodes Rotylenchulus reniformis was highest frequency of occurrence (196), followed by Hoplolaimus indicus (104), Tylenchorhynchus mashhoodi (84), Helicotylenchus dihystera (80) and the least frequency of occurrence Meloidogyne spp. (20).

With the absolute frequency higher Rotylenchulus reniformis (81.67\%), followed by Hoplolaimus indicus (43.33\%), Tylenchorhynchus mashhoodi (35\%), Helicotylenchus dihystera $(33.33 \%)$ and the least absolute frequency Meloidogyne spp.(8.33\%).Relative frequency of Rotylenchus reniformis was recorded maximum (14.33\%), followed by Hoplolaimus indicus (7.60\%), Tylenchorhynchus mashhoodi (6.14\%), Helicotylenchus dihystera $(5.85 \%)$ and the least relative frequency found in Meloidogyne spp.(1.46\%). Rotylenchulus reniformis occurred in high densities, which was (230) nematodes per 200cc soil followed by Helicotylenchus dihystera (62.50), Meloidogyne spp. (40.40), Tylenchorhynchus mashhoodi (36.38), Hoplolaimus indicus (30.03) and the lowest density found in Aphelenchus avenae (8.73). Among the plant parasitic nematodes Rotylenchulus reniformis was found above Pathogenic level which cause disease incidence in fruit crops in different places of Bhubaneswar. Other nematode species reflected low densities which were below pathogenic level. Highest relative densities was recorded in Rotylenchulus reniformis (39.65\%) followed by Helicotylenchus dihystera (10.77\%), Meloidogyne spp. (6.96\%), Tylenchorhynchus mashhoodi (6.27\%), Hoplolaimus indicus $(5.18 \%)$ and the lowest density found in Aphelenchus avenae (1.50\%). In consideration to prominence value of plant parasitic nematodes Rotylenchulus reniformis exhibited highest Prominence value (207.85), followed by Helicotylenchus dihystera (36.08), Tylenchorhynchus mashhoodi (21.52), Hoplolaimus indicus (19.77), Meloidogyne spp(11.66) and Aphelenchus avenae found the lowest prominence value as (3.74).

So far as the free living nematodes are concerned Dorylaimids were having the highest frequency of occurrence (232) with absolute frequency $(96.67 \%)$ followed by Rhabditid (93.33\%) and Mononchid (80\%). Dorylaimid was also having highest density (52.68) followed by Rhabditid (36.64) and Mononchid (23.79).

Among nematodes encountered from 240 samples, overall Dorylaimid $(\mathrm{PV}=51.79)$ and Rhabditid ( $\mathrm{PV}=35.40)$ were as the most frequent nematodes but Rotylenchulus reniformis was the most prominent species in context to density of Prominence value. As regards to cashewnut, Aphelenchus avenae, Hoplolaimus indicus, Rotylenchulus reniformis, Tylenchorhynchus mashhoodi as plant parasitic nematodes and Dorylaimids, Mononchids and Rhabditids as free living nematodes were reported. Among them Dorylaimid was the most Prominent species followed by Rhabditids and Tylenchorhynchus mashhoodi. But (Orisajo, 2012) while surveying seven localities in North Central Nigeria found ten plant parasitic nematodes when Meloidogyne spp., Helocotylenchus coffeae and Radopholus spp. were wide spread in all localities and Rotylenchulus reniformis in three locations. But Rotylenchulusreniformis in cashewnut as per the current result was found in Nine locations. The variation might be due to various edaphic factors. 
Table.1 Occurrence and distribution of nematode species associated with different fruit crops in localities of Bhubaneswar, Odisha, India

\begin{tabular}{|c|c|c|c|c|c|c|c|c|c|c|c|c|c|c|c|}
\hline \multirow{2}{*}{$\begin{array}{l}\text { SL. } \\
\text { No }\end{array}$} & \multirow{2}{*}{$\begin{array}{l}\text { Name of } \\
\text { the Fruit } \\
\text { crops }\end{array}$} & \multirow{2}{*}{$\begin{array}{c}\text { No. of } \\
\text { sample } \\
\text { collected }\end{array}$} & \multicolumn{13}{|c|}{ Soil sample containing nematode species(No.) } \\
\hline & & & Aa & Ch & Hd & Hm & Hi & Ms & Pc & $\mathbf{R r}$ & Tm & $\mathbf{X i}$ & D & $\mathbf{M}$ & $\mathbf{R}$ \\
\hline 1 & Cashewnut & 60 & 24 & - & - & - & 28 & - & - & 36 & 40 & & 52 & 52 & 52 \\
\hline 2 & Guava & 60 & 20 & 12 & 20 & 8 & 16 & 20 & 36 & 44 & 28 & 20 & 60 & 40 & 52 \\
\hline 3 & Lime & 60 & - & 16 & 24 & 24 & 28 & - & 16 & 56 & - & 16 & 60 & 48 & 60 \\
\hline 4 & Papaya & 60 & - & 16 & 36 & 12 & 32 & - & - & 60 & 16 & 16 & 60 & 52 & 60 \\
\hline & Total & 240 & 44 & 44 & 80 & 44 & 104 & 20 & 52 & 196 & 84 & 52 & 232 & 192 & 224 \\
\hline
\end{tabular}

(Aphelenchus avenae (Aa), Caloosia heterocephala (Ch), Helicotylenchus dihystera (Hd), Hemicriconemoides mangiferae (Hm), Hoplolaimus indicus (Hi), Meloidgyne spp.(Ms) Pratylenchus coffeae (Pc), Rotylenchulus reniformis (Rr),Tylenchorhynchus mashhoodi (Tm), Xiphinema insigne (Xi), Dorylaimid (D), Mononchid $(M)$, Rhabditid (R).

Table.2 Prominence, frequency of occurrence and population density of nematodes associated with fruit crops in Bhubaneswar, Odisha

\begin{tabular}{|c|c|c|c|c|c|c|c|c|}
\hline $\begin{array}{l}\text { Sl. } \\
\text { No }\end{array}$ & Nematode species & $\begin{array}{l}\text { Total no. } \\
\text { of } \\
\text { samples } \\
\text { collected }\end{array}$ & $\begin{array}{l}\text { No. of } \\
\text { samples } \\
\text { containing } \\
\text { the species }\end{array}$ & $\begin{array}{l}\text { Absolute } \\
\text { frequency }\end{array}$ & $\begin{array}{l}\text { Relative } \\
\text { frequency }\end{array}$ & $\begin{array}{l}\text { Absolute } \\
\text { density }\end{array}$ & $\begin{array}{l}\text { Relative } \\
\text { density }\end{array}$ & $\begin{array}{l}\text { Prominenc } \\
\text { e value }\end{array}$ \\
\hline 1 & $\begin{array}{l}\text { Aphelenchus } \\
\text { avenae }\end{array}$ & 240 & 44 & 18.33 & 3.22 & 8.73 & 1.50 & 3.74 \\
\hline 2 & $\begin{array}{l}\text { Caloosia } \\
\text { heterocephala }\end{array}$ & 240 & 44 & 18.33 & 3.22 & 20.90 & 3.60 & 8.95 \\
\hline 3 & $\begin{array}{l}\text { Helicotylenchus } \\
\text { dihystera }\end{array}$ & 240 & 80 & 33.33 & 5.85 & 62.50 & 10.77 & 36.08 \\
\hline 4 & $\begin{array}{l}\text { Hemicriconemoies } \\
\text { mangiferae }\end{array}$ & 240 & 44 & 18.33 & 3.22 & 13.63 & 2.35 & 5.84 \\
\hline 5 & $\begin{array}{l}\text { Hoplolaimus } \\
\text { indicus }\end{array}$ & 240 & 104 & 43.33 & 7.60 & 30.03 & 5.18 & 19.77 \\
\hline 6 & Meloidogyne spp. & 240 & 20 & 8.33 & 1.46 & 40.40 & 6.96 & 11.66 \\
\hline 7 & $\begin{array}{l}\text { Pratylenchus } \\
\text { coffeae }\end{array}$ & 240 & 52 & 21.67 & 3.80 & 12.61 & 2.17 & 5.87 \\
\hline 8 & $\begin{array}{l}\text { Rotylenchulus } \\
\text { reniformis }\end{array}$ & 240 & 196 & 81.67 & 14.33 & 230.00 & 39.65 & 207.85 \\
\hline 9 & $\begin{array}{l}\text { Tylenchorhynchusma } \\
\text { shhoodi }\end{array}$ & 240 & 84 & 35.00 & 6.14 & 36.38 & 6.27 & 21.52 \\
\hline 10 & Xiphinema insigne & 240 & 52 & 21.67 & 3.80 & 11.84 & 2.04 & 5.51 \\
\hline 11 & Dorylaimid & 240 & 232 & 96.67 & 16.96 & 52.68 & 9.08 & 51.79 \\
\hline 12 & Mononchid & 240 & 192 & 80.00 & 14.04 & 23.79 & 4.10 & 21.28 \\
\hline \multirow[t]{2}{*}{13} & Rhabditid & 240 & 224 & 93.33 & 16.37 & 36.64 & 6.32 & 35.40 \\
\hline & & & & 570.00 & 100.00 & 580.13 & 100.00 & \\
\hline
\end{tabular}


So far as association of nematodes in guava was concerned guava was the only fruit crop where all ten plant parasitic and three free living nematodes were reported. This corroborates the findings of (Khan et al., 2007), who also reported ten plant parasitic nematodes. Moreover Rotylenchulus reniformis was adjudged with most prominent species. But the present results contradicts to (Ansari and Khan, 2012) who made extensive survey of plant parasitic nematodes in 14 localities of Aligarh and found Meloidogyne spp. as the most prominent spp, followed by Hoplolaimus spp. Climate of Aligarh and the varieties of guava differ from the Odisha climate and the varieties of guava might have contributed variations in prominence of different plant parasitic nematodes.

With respect to nematode diversity in lime, seven plant parasitic nematodes and three groups free living nematodes altogether ten genera were recorded. This is in consonance with the results of (Vyas et al., 2008), who also surveyed lime crop reporting 8 genera of nematodes. The present report contradicts the results of (Ganguly, 1988), who found high density of Xiphinema basiri and moderate population of Rotylenchulus reniformis. This might have resulted because Rotylenchulus reniformis is more adopted than Xiphinema spp. in Odisha, but in Northen state Xiphinema spp. might be more adopted compared to Rotylenchulus reniformis.

In context to association of nematodes in papaya, it was observed that seven plant parasitic and three groups of free living nematodes were found in the rhizosphere of papaya. Rptylenchulus reniformis obtained $100 \%$ Absolute frequency, considering this species as the most prominent nematode, followed by Helicotylenchus dihystera, the least prominent nematode being Xiphinema insigne, Rotylenchulus reniformis as the most prominent species was also reported by (Mc
Sorley, 1992), (Castillo and Barcina,1993), (Ganguly et al., 1995) and (Sayeed et al., 2008).

It is concluded that, Rotylenchulus reniformis is adjudged as the most prominent species in guava, lime, papaya and Dorylaimids in cashewnut. Similarly least prominent species was recorded as Hemicriconemoides mangiferae in guava, Xiphinema insigne in lime and papaya, Aphelenchus avenae in cashewnut, but altogether in four fruit crop Aphelenchus avenae was considered as the least prominent species.

\section{Acknowledgement}

Dr. N. K. Sahoo, Former Professor and Head, Department of Nematology, College of Agriculture, O.U.A.T. is highly acknowledged.

\section{References}

Ansari, R.A. and Khan, T.A. (2012). Diversity and community structure of phytonematodes associated with Guava in and Around Aligarh, Uttar Pradesh, India. Trends in Bioscience. 5(3): 202204.

Castillo, P. and Barcina, G. (1993). Plant parasitic nematodes associated with tropical and sub tropical crops in Southern Spain. Nematology Mediterranean. 21, 45-47.

Cobb, N.A. (1918). Estimating the nematodes population of soil Agric Tech. Circ. US. Deptt. Agric. 1, 1-48.

Ganguly, S., Tripathi, M.N. and Ghayyur, U. (1995). The reniform nematode, Rotylenchulus reniformis- A threat to papaya cultivation. Indian Journals. 27(1): 135-136.

Ganguly, S. (1989). Phytonematodes associated with betelvine and citrus in Nagpur, Maharashtra, India. Indian 
Journal of Nematology. 18(1): 142-144.

Khan, M. R., Hassan, A., Ghosh, B., Das, B., Ghosh, S. and Ray, S.K. (2007). Diversity and community analysis of soil nematodes associated with guava from west bengal, india. ActaHorticulturae. 735(5): 210-245.

Mc, Sorley, R. (1997). Relationship of crop and rainfall to soil nematode community structure in perennial agroecosystems. Applied Soil Ecology. 6(2): 147-153.

Norton, D.C. (1978). Ecology of plant parasitic nematodes. A Wiley Interscience Publication. Jhon Wiley and Sons. New York. 268pp.

Orisajo, S.B. (2012). Distribution and effect of plant-parasitic nematodes associated with Cashew in North Central-Nigeria. Agricultural Journal. 7(6): 405-407. fauna of Orissa. Published from Department of Nematology, OUAT, Bhubaneswar. 1-48.

Sayed, M., Khan, A., Bilquees, F.M. and Khatoon, N. (2008). Histopathology of papaya roots infected by Rotylenchulus reniformis. Pakistan Journal of Nematology. 26(1): 29-35.

Vyas, N., Kadela, P., Nama, P. and Deepika, Y. (2008). Community analysis of plant- parasitic nematodes in and around IGNP region of Jaisalmer, Rajasthan. Journal of Experimental Zoology, India. 11(2): 415-417.

Southey, J.F. (1986). Laboratory methods for work with plant and soil nematodes. Ministry of Agriculture, Fisheries and food, H.M.S.O., London. p 202.

Ray, S. and Das, S.N. (1998). Nematode

\section{How to cite this article:}

Pranaya Pradhan, Mukesh Kumar Patra and Niranjan Kumar Sahoo. 2020. Association of Nematodes with Fruit Crops in Bhubaneswar, India. Int.J.Curr.Microbiol.App.Sci. 9(05): 19181923. doi: https://doi.org/10.20546/ijcmas.2020.905.219 